AMERICAN JOURNAL OF SOCIAL AND MANAGEMENT SCIENCES

ISSN Print: 2156-1540, ISSN Online: 2151-1559, doi:10.5251/ajsms.2012.3.3.99.105

(C) 2012, ScienceHuß, http://www.scihub.org/AJSMS

\title{
Attitude of women farmers towards agricultural extension services in Ifelodun local government area, Osun State
}

\author{
Ayoade Adenike Rebecca
}

\author{
Department of Agricultural Economics and Extension, Ladoke Akintola University of \\ Technology, Ogbomosho, Oyo State, Nigeria
}

\begin{abstract}
ABSTACT
The focus of this study was on the attitude of women farmers towards extension service in Ifelodun Local Government area of Osun State. Simple random sampling technique was used in the selection of ninety women farmers for the study. Structured interview schedule was used to elicit information from the respondents. The data were analyzed using descriptive statistics like frequency counts, mean, percentages, while Pearson Product Moment Correlation was used to test the relationship between the dependent and independent variables. The findings showed that majority of the respondents agreed that extension service helps women farmers to adopt new technologies. The most accessible extension service is demonstration of improved technology among others, and the major challenge faced is that of financial constraints in purchasing inputs. However, a significant relationship exist between the farm size, type of crop grown and the women's attitude towards extension service. It is therefore recommended that government should make provision for financial aid to the farmers so as to increase their productivity.
\end{abstract}

Keywords: Woman, farmer, attitude, Nigeria

\section{INTRODUCTION}

Attitude is the degree of positive or negative effect associated with psychological objects and one major approach to determine the impact of extension service is to begin with the farmers' attitude. The employment of more qualified and experienced extension agents, especially subject matter specialist and the adoption of the farmer first approach to agricultural research and development are recommended for farmers to show a positive attitude towards the extension service ( Oladosu,2006). As technology improves by the day, several approaches have evolved and been applied to ensure effective dissemination of extension service so as to improve the living standard of rural farmers in Nigeria. It was in the cause of this quest that it was found that the role of rural women farmers was very important and could not be undermined when targeting an increase in productivity and living standard of the farmers. According to Olawoye (1991), rural women as well as men throughout the world are engaged in a range of productive activities essentials to household welfare, agricultural productivity and economic growth. Agricultural extension strategies traditionally have focusssed on increasing production of cash crops by providing men with training, information and access to inputs and services. This male bias is illustrated in farmer training centers which have been established to provide residential training on technical subjects. Most do not provide separate washing and sleeping accommodations for men and women and do not provide facilities for the care of babies and young children which are factors which may prevent women from attending centers. Secondly, womens' daily workloads do not usually allow them to be absent from home for residential training, even attending short courses may cause insuperable problems in arranging substitute care for children or the home ( Jamison and Orival, 1983)

The female gender (women) contributes the bulk of production output for each year in recent times. Hence, the need to bring the female gender into the main stream/core of extension service activities so as to ensure increased agricultural productivity. However, persistent problems of gender discrimination, poverty, inadequate access to land and credit facilities, social cultural factors etc has continually been a bane to the success and implementation of Agricultural Extension service. Women form half of the world and rural area population. And for them to play a more active role in food security, sustainable farming and rural development, there is the need to provide rural women with more qualified, reliable and convenient information continuously and on timely basis. (Kizilastan, 2007)

It has also been observed and established that the involvement of rural women in agricultural production has been of significance to the country's economic 
development. Empirical studies have revealed that women perform such works as hoeing, sowing, weeding, harvesting, processing and several other activities related to agricultural production (Ani et al, 2004). However, it is pertinent to note that the success of any extension programme depends largely on the attitude of the duo (Clientele \& Agent). But essentially, dissemination of technologies compatible with existing farm practices encourage a positive attitude towards change, improve the agent's credibility and may also encourage faster adoption of innovations.

Several studies and researches have been carried out on the attitude of farmers to agricultural extension programmes, and also its consequent effects on productivity and the economy at large.

For agricultural service and programme to be more successful and effective, effort should be made at creating the right attitude and mindset both with the clientele and the agent. Though, so many factors are responsible for poor dissemination of extension service to women farmers, it is quite expedient to note that the attitude of female farmers might as well be a contributing factor to ineffective delivery of extension service programme. Through the activities of Women in Agriculture (WIA) unit of OSADEP, OSADEP has introduced several strategic programmes aimed at bringing women farmers into the forefront of agricultural production. It is however, difficult to really specify where the problems of ineffective delivery of agricultural extension services to women farmers lie. This study therefore, assessed the attitude of female farmers to extension service rendered by extension agents in the study area. Specifically, the study identified the socio-economic characteristics of women farmers in the study area as well as determined the accessibility of farmers to the extension service being provided. Also, the study evaluated the effects of extension service on Agricultural production in the study area and finally determined the challenges encountered by farmers in accessing extension services in the locality.

Based on the objectives of the study, a significant relationship between the socio-economic characteristics of women farmers and their attitude towards extension service was determined.

\section{METHODOLOGY}

Data for the study were collected from sampled women farmers in the study area. The study was conducted in ifelodun Local Government area of Osun State, Nigeria. Respondents were simple randomly selected from the sample frame of registered women farmers with the state WIA supervisor. Data and information were collected via fortnight visit to two major farm settlements in the town with sample size of about (45) forty five female farmers in each settlement. The data collection was done through structured interview schedule and the informations collected were based on the objectives of the study. The attitude of the female farmers which is the dependent variable was measured by a list of questions that sought the attitude of the female farmers towards agricultural extension service. To achieve this, a five point likert scale containing strongly agree (SA) five points to strongly disagree (SD) one point was developed.

Independent variables used in the research work include socio-economic characteristics such as age, marital status, level of education, number of children, size of farm, religion etc. Data analyses were done using both descriptive and inferential statistics like frequencies counts, percentages and correlation analysis was used to test for the significance of the relationship between the attitude scores of the respondents as indicated by the scores of the likert scale analysis and their socio-economic characteristics.

\section{FINDINGS AND DISCUSSION}

Socio-economic characteristics of women farmers: The age distribution of the respondents revealed that the age bracket of 31-40yrs constitutes the largest age class of about $37.8 \%$ of the total respondents. The age class $51-60$ and $41-50$ follows with $24.5 \%$ and $21.1 \%$ respectively. The mean age of the respondents was 41.8 , which might imply that most of the respondents are middle aged and this strongly suggests that the majority of the respondents were agile and active youths who could still actively engage in agricultural activities. About $62.2 \%$ of the total respondents were married, while $25.6 \%$ were single. Also, $12.2 \%$ of the respondents were widowed. This is to say that the majority of the respondents were married and may have the support of their spouses and children in participating in agricultural extension activities. The household size indicates that the majority of the respondents have between 6-10 members in their household. This constitutes about $56.7 \%$ of the total respondents. The mean household size is 7.9 which could be said to be high on the average. However, this may have favoured the supply of labour for farm activities. The findings of the study revealed that $64.5 \%$ of the total respondents had acquired one form of formal 
education or the other. This suggests therefore that there is a relatively high level of literacy among the respondents and this may have influenced their positive attitude towards extension service. About $64.5 \%$ of the total respondents have had about 6$10 \mathrm{yrs}$ of active farming experience. The mean number of years of farming experience was 7.6yrs. 82.2 percent of the respondents had a total farm size ranging between 1-5 acres. This strongly suggests that most of the women farmers in the locality operated on a small scale. The research work showed that $82.2 \%$ of the respondents had farming as their primary occupation while about $17.8 \%$ had other occupations as their primary occupations, but also had farming as a secondary occupation. This simply implies that farming is a basic source of livelihood for the women and requires a more effective concentration of extension service.

Awareness of extension services: The findings of the study revealed that majority $(86.7 \%)$ of the respondents were quite aware of extension services and activities in the study area. This strongly suggests that most of the respondents were likely working in conjunction with an extension agent.

Accessibility to basic extension services: Table 3 reveals a list of common extension services rendered by extension agents and how accessible they are to farmers in the study area." Demonstration of improved technologies" was the most accessible service with a weighted mean score of 1.31 . This was followed by the "distribution of improved seeds" (1.26) and "access to required agricultural knowledge" (1.24). Other relatively accessible services includes provision of loans and credit (1.07), distribution of fertilizers at subsidized rate (1.06), access to improved farm inputs (1.04), provision of veterinary services (0.84). However, provision of home economics skills and health care (0.68), provision of marketing channels (0.68) and provision of tractors (0.37) were least accessible extension service.

Effects of extension services on farmers production: Extension services are more than often aimed at influencing farmers' attitude, knowledge and skill which thereby also positively influence farmers' production. The table 4 shows a list of effects which farmers in the study area had benefitted from. "Access to improved farm inputs was the most prominent effect with $74.4 \%$ of the respondents attesting to it. This was closely followed by "decrease in the cost of production" $(73.3 \%)$, "access to subsidized farm inputs and equipment" (72.2\%).
Other positive effects include "increase in income and revenue" $(68.9 \%)$, increased production and output level $(66.7 \%)$, access to loans and credit facilities $(65.6 \%)$, better storage conditions for excess production $(62.2 \%)$, increased access to marketing facilities $(55.6 \%)$. However, the least prominent effects were increased technical knowhow (53.3\%) and decrease in pest and disease (52.8\%). These simply suggest that lack of technical knowhow and incident cases of pest and diseases are likely to be prevalent in the study area.

Challenges to women's accessing extension service: Table 5 shows that the most prominent of these challenges was "financial constraint in purchasing inputs" with $83.3 \%$ of the respondents being victims. This was followed by "lack of collateral for granting loans" (82.2\%), "man-know-man (influence and sentiments) problems" (75.6\%). Other problems associated with accessing extension services include administrative bottlenecks (71.1\%), insensitivity on the part of government $(61.1 \%)$, late delivery of fertilizers $(57.8 \%)$, inadequate supply of farm inputs $(45.6 \%)$, poor communication skills $(43.3 \%)$, lack cooperation among farmers (38.9\%), etc. The least challenging of these of these problems was unavailability of extension agent (18.9\%). These simply suggest that the most prevalent problems were more due to socio-economic factors on the part of the farmers and administrative problems.

Women farmers attitudinal statements: This section aimed at evaluating individual farmer's perception and views about extension agent and services in the study area. Majority of the farmers agreed to the fact that extension agents were expected to "motivate farmers to adopt new technologies" with a weighted mean score of 4.23 . Farmers also supported the view that extension agents were expected to help farmers acquire needed knowledge (3.88) and supply information about agricultural practices (3.69). However, most farmers disagreed with the idea that extension agent help farmers analyze their present/future situation (2.87), provides and improves social amenities (2.58), and generation of employment (2.39). This implies that of the women farmers hold the view that an extension agent function was more educational, information and knowledge inclined rather than meeting farmer's material need.

Correlation analysis between socio-economic characteristics and attitudinal statements: From the table 7 below, the result of the analysis showed that there is a positive and significant relationship 
between the total farm size and the women's attitude at 0.01 level of significance $(r=0.277$ $\left.P^{*}=0.01\right)$. This simply implies that the larger the farm size of the respondents, the more positive their attitude to extension services. This may be due to the fact that large scale farmers would rather prefer carrying out recommended farming practices than risk ignoring it and incurring huge financial losses. Also, large scale farmers are often eager to try out new recommended practices in order to improve their yield and productivity. A significant but negative relationship was also found to exist between the type of crop grown and the women's attitude at 0.05 level of significance $(r=-0.213, P=0.05)$. This implies that farmer's attitude to extension services are negatively related to the type of crop grown. This is to say that farmers attitude are most likely to be negative if the services provided by extension agents are not relevant to the type of crop grown by the farmers.

Table 1:Distribution of respondents by socio economic characteristics.

\begin{tabular}{|c|c|c|}
\hline Age & Frequency & Percentage (\%) \\
\hline $21-30$ & 12 & 13.3 \\
\hline $31-40$ & 34 & 37.8 \\
\hline $41-50$ & 19 & 21.1 \\
\hline $51-60$ & 22 & 24.5 \\
\hline $61-70$ & 3 & 3.3 \\
\hline Total & 90 & 100.0 \\
\hline Marital status & Frequency & Percentage (\%) \\
\hline Single & 23 & 25.6 \\
\hline Married & 56 & 62.2 \\
\hline Divorced & 11 & 12.2 \\
\hline Total & 90 & 100.0 \\
\hline Household Size & Frequency & Percentage (\%) \\
\hline $1-5$ & 19 & 21.1 \\
\hline $6-10$ & 51 & 56.7 \\
\hline $11-15$ & 19 & 21.1 \\
\hline $16-20$ & 1 & 1.1 \\
\hline Total & 90 & 100.0 \\
\hline Level of Education & Frequency & Percentage (\%) \\
\hline Non-formal & 32 & 35.5 \\
\hline Primary uncompleted & 9 & 10.0 \\
\hline Primary completed & 21 & 23.3 \\
\hline Secondary uncompleted & 6 & 6.7 \\
\hline Secondary completed & 15 & 16.7 \\
\hline Tertiary & 7 & 7.8 \\
\hline Total & 90 & 100.0 \\
\hline Years of Farming Experience & Frequency & Percentage (\%) \\
\hline $1-5$ & 22 & 24.4 \\
\hline $6-10$ & 58 & 64.5 \\
\hline $11-15$ & 7 & 7.8 \\
\hline $16-20$ & 3 & 3.3 \\
\hline Total & 90 & 100.0 \\
\hline Total Farm Size & Frequency & Percentage (\%) \\
\hline $1-5$ & 74 & 82.2 \\
\hline $6-10$ & 14 & 15.6 \\
\hline $11-15$ & 2 & 2.2 \\
\hline Total & 90 & 100.0 \\
\hline Occupation & Frequency & Percentage (\%) \\
\hline Primary Occupation (Farming) & 74 & 82.2 \\
\hline Secondary Occupation (Farming) & 16 & 17.8 \\
\hline Total & 90 & 100.0 \\
\hline
\end{tabular}


Am. J. Soc. Mgmt. Sci., 2012, 3(3): 99-105

Table 2: Distribution of respondents according to awareness of extension services.

\begin{tabular}{|ccc|}
\hline Awareness of Extension service & Frequency & Percentage (\%) \\
\hline Yes & 78 & 86.7 \\
No & 12 & 13.3 \\
& & \\
\hline Total & 90 & 100.0 \\
\hline
\end{tabular}

Table 3:Distribution of respondents' access to basic extension services.

\begin{tabular}{|c|c|c|c|c|c|c|}
\hline Services & V.A & $\mathbf{A}$ & $\mathbf{N} \cdot \mathbf{A}$ & Score & WMS & Rank \\
\hline Demonstration of improved technologie & s $32(35.6)$ & $54(60)$ & $4(4.4)$ & 118 & 1.31 & $1^{\text {st }}$ \\
\hline Distribution Of subsidized improved see & d31 (34.4) & $51(56.7)$ & $8(8.9)$ & 113 & 1.26 & $2^{\text {nd }}$ \\
\hline Access to required Agric knowledge & $30(33.3)$ & $52(57.8)$ & $8(8.9)$ & 112 & 1.24 & $3^{\text {rd }}$ \\
\hline Provision of loans and credit facilities & $25(27.8)$ & $47(52.2)$ & $18(20.0)$ & 97 & 1.07 & $4^{\text {th }}$ \\
\hline Distribution of fertilizers at subsidized ra & at26 (28.9) & $43(47.8)$ & $21(23.3)$ & 95 & 1.06 & $5^{\text {th }}$ \\
\hline Access to improved farm inputs & $24(26.7)$ & $46(51.1)$ & $20(22.2)$ & 94 & 1.04 & $6^{\text {th }}$ \\
\hline Provision of veterinary services & $14(15.6)$ & $48(53.3)$ & $28(31.1)$ & 76 & 0.84 & $7^{\text {th }}$ \\
\hline Provision of home econs skills\&health c & are $6(6.7)$ & $49(54.4)$ & 35(38.9) & 61 & 0.68 & $8^{\text {th }}$ \\
\hline Provision of marketing facilities & $8(8.9)$ & $45(50)$ & $37(41.1)$ & 61 & 0.68 & $8^{\text {th }}$ \\
\hline Provision of tractors for farm operation & $3(3.3)$ & $27(30)$ & $60(66.7)$ & 33 & 0.37 & $10^{\text {th }}$ \\
\hline
\end{tabular}

VA : Very Accessible, A : Accessible, NA: Not Accessible.

Table 4:Distribution of effects of extension services on the respondents

\begin{tabular}{|lcc|}
\hline \multicolumn{1}{|c}{ SERVICES } & FREQUENCY & (\%) \\
\hline Access to improved farm inputs & 67 & 74.4 \\
Decrease in cost of production & 66 & 73.3 \\
Access to subsidized farm inputs and equipment & 65 & 72.2 \\
Increase in income and revenue & 62 & 68.9 \\
Increased production and output level & 60 & 67.7 \\
Access to loan and credit facilities & 59 & 65.6 \\
Better storage conditions for excess production & 56 & 62.2 \\
Increased access to marketing facilities & 50 & 55.6 \\
Increased technical know-how & 48 & 53.3 \\
Decreased in pest and disease problems & 47 & 52.2 \\
\hline
\end{tabular}


Am. J. Soc. Mgmt. Sci., 2012, 3(3): 99-105

Table 5: Distribution of common challenges encountered by respondents in accessing extension services.

\begin{tabular}{|lcc|}
\hline \multicolumn{1}{|c|}{ CHALLENGES } & ${ }^{*}$ FREQUENCY & $(\%)$ \\
\hline Financial constraint in purchasing inputs & 75 & 83.3 \\
Lack of collateral for granting loans & 74 & 82.2 \\
Man know man problems & 68 & 75.6 \\
Administrative bottlenecks & 64 & 71.1 \\
Insensitivity on the part of government & 55 & 61.1 \\
Late delivery of fertilizers & 52 & 57.8 \\
Inadequate supply of farm input & 41 & 45.6 \\
Poor communication skills & 39 & 43.3 \\
Lack of cooperation among farmers & 35 & 38.9 \\
Lack of time to attend to extension meetings & 32 & 35.6 \\
Rift between farmer and extension agent & 24 & 26.7 \\
Lackadaisical attitude on the part of extension agent & 21 & 23.3 \\
Unavailability of extension agent & 17 & 18.9 \\
\end{tabular}

Table 6: Summary of respondents' attitudinal statements

\begin{tabular}{|c|c|c|c|c|c|c|c|}
\hline ATTITUDINAL STATEMENTS & SA & $\mathbf{A}$ & $\mathbf{U}$ & D & SD SCORE & WMS & RANK \\
\hline Motivate farmers to adopt new technology & $13(14.4)$ & $50(55.6)$ & $4(4.4)$ & 18(20.0) & $5(5.6) \quad 381$ & 4.23 & $1^{\text {st }}$ \\
\hline Help farmers to acquire needed knowledge & $14(15.6)$ & ) $64(71.1$ & $3(3.33)$ & $5(5.6)$ & $4(4.4) \quad 349$ & 3.88 & $2^{\text {nd }}$ \\
\hline Supply information about agricultural service & $12(13.3)$ & $57(63.3)$ & $9(10.0)$ & $6(6.7)$ & $5(5.6) \quad 332$ & 3.69 & \\
\hline Improving farmers output & $9(10.0)$ & $58(64.4)$ & $5(5.6)$ & $10(11.1)$ & $8(8.9) 320$ & 3.56 & $4^{\text {th }}$ \\
\hline Serve as a link between government and farmers & $9(10.0)$ & $46(51.1$ & ) $14(15.6)$ & ) $17(18.9)$ & $4(4.4) \quad 309$ & 3.43 & $5^{\text {th }}$ \\
\hline Demonstrate improved technologies to farmers & $13(14.4)$ & $53(58.9)$ & $7(7.8)$ & $9(10.0)$ & $8(8.9) \quad 299$ & 3.32 & $6^{\text {th }}$ \\
\hline Teaches home econs to improve farmers livelihood & $11(12.2)$ & $30(33.3)$ & $25(27.8)$ & $17(18.9)$ & $7(7.8) 291$ & 3.23 & $7^{\text {th }}$ \\
\hline Help farmers in their decision making & $5(5.6)$ & $39(43.3)$ & $17(18.9)$ & $18(20.0)$ & $10(11.1) 278$ & 3.09 & $8^{\text {th }}$ \\
\hline Help farmers analyze present/future situations & $7(7.8)$ & $18(20.0)$ & $32(35.6)$ & $22(24.4)$ & $11(12.2) 258$ & 2.87 & $9^{\text {th }}$ \\
\hline Providing and improving socio amenities & $2(2.2)$ & $17(18.9)$ & $21(23.3)$ & $41(45.6)$ & $9(10.0) \quad 232$ & 2.58 & $10^{\text {th }}$ \\
\hline Generation of employment & $3(3.3)$ & $13(14.4)$ & $16(17.8)$ & $42(46.7)$ & $16(17.8) 215$ & 2.39 & $11^{\text {th }}$ \\
\hline
\end{tabular}

Table 7: Summary of correlation analysis between socio-economic characteristics and attitudinal statements

\begin{tabular}{|lcc|}
\hline \multicolumn{1}{|c|}{ Variable } & r value & Remark \\
\hline Age & -0.137 & Not Significant \\
Religion & -0.58 & Not Significant \\
Marital Status & 0.14 & Not Significant \\
Household Size & 0.72 & Not Significant \\
Level of Education & 0.094 & Not Significant \\
Farming experience & -0.122 & Not Significant \\
Number of Farm locations & 0.22 & Not Significant \\
Total Farm size & $0.277^{\star *}$ & Significant \\
Primary occupation & -0.004 & Not Significant \\
Secondary occupation & -0.129 & Not Significant \\
Type of crop grown & $-0.213^{*}$ & Significant \\
\hline
\end{tabular}

** Correlation significant at the 0.01 level

* Correlation significant at the 0.05 level

\section{CONCLUSIONS AND RECOMMENDATION}

The findings in the study revealed that majority of the women were agile and actively involved in
Agricultural activities, and that the high level of literacy among the respondents was responsible for their positive attitude to extension service. The study also revealed that "Demonstration of improved technologies" and "Distribution of subsidized seeds" were the most accessible extension services. Also, 
lack of technical know-how and incident cases of pest and diseases were revealed to be prevalent in the study area. Furthermore, financial constraints and lack of collateral to secure loans are the prominent challenges encountered in having access to extension services in the study area. And finally the study revealed that Farm size and the type of crop grown have influence on women farmers' attitude towards extension service. Based on the findings of this study, it is recommended that:

1. Extension agents should endeavor to foster better working relationships between themselves and the women farmers as this would grant them more freedom to express their plight and challenges better.

2. Efforts should be geared towards increasing the technical manpower of farmers and also reduce the incidence of pest and diseases in the study area. This will amount to increased level of production and in turn increased income for the women farmers.

3. Financial aid should be granted to the women to cushion the effects of financial constraints in accessing extension services and lack of collateral in securing loans. These would also furthermore boost their morale in exploring the benefits of extension service.

\section{REFERENCES}

Adeola R.G, Ayoade A.R (2009): Effect of gender discrimination in access to technologies among farmers in Ibadan/lbarapa Agricultural zone of Oyo state Nigeria. Ozean Journal of social sciences, Vol. 2, No. 2, page 66.

Akeredolu M.O (2008): Private sector involvement in Agricultural extension service delivery in Mali. Proceedings of the $24^{\text {th }}$ annual AIAEE Meeting, page 2.
Ani A.O, O. Ogunnika, S.S Ifah (2004): Relationship between socio-economic characteristics of rural women farmers and their adoption of farm technologies in southern Ebonyi state,Nigeria. International Journal of Agriculture \& Biology, Vol. 6, No. 5, page 1.

Arokoyo T (2008): ICT's in the transformation of Agricultural extension service: The case study of Nigeria. Page $3,4,5,6$.

CBN 2010: www.cenbank.org.

FAO 2009: Uplift and empowerment of rural women (farmer's wife). www.fao.org.

FAO 2009: Constraints to Agricultural extension and training. www.fao.org.

http://fao.org/docrep/v4805e: Improving the relevance and effectiveness of Agricultural extension activities.

Jamali . K . (2009): The role of rural women in Agriculture and its Allied fields: A case study of Pakistan. European Journal of social sciences, Vol. 7, No. 3, page 73.

Kizilastan .N. (2007): Rural women in Agricultural extension training. Research Journal of Social Science, Vol. 2, No. 1, page 23.

Mundi N.E (2009): Provision of Agricultural extension service for the rehabilitation of physically challenged children through open and distance learning in Nigeria. Page 3, 4, 5.

Ogunlela I.O, Mukhtar A.A (2009): Gender issues in Agriculture and rural development in Nigeria: The role of women. Humanity \& social sciences Journal, Vol. 4, No. 1, page 19, 24.

Okunade E.O (2007): Effectiveness of extension teaching methods in acquiring knowledge, skill and attitude by women farmers in Osun state. Journal of applied sciences research, Vol. 3, No. 4, page 289.

Oladosu I.O ( 2006): Implications of Farmers' Attitude Towards Extension Agents on Future Extension Program me Planning in Oyo State of Nigeria. Journal of Social Sciences 12(2) 115-118 pg 2006 